\title{
INTERACTION OF SCIENCE, GOVERNMENT AND INDUSTRY IN NEW ZEALAND
}

$\mathrm{I}^{\mathrm{N}}$ a recent issue of the New Zealand Science Review (21, No. 3; 1963) Dr. R. M. Williams, of the State Service Commission, Wellington, discusses the responsibility of Government in scientific research and development. Distinguishing between research primarily directed at exploiting existing knowledge and that which primarily aims at extending knowledge, rather than between pure and applied research, he considers five ways in which Government can promote research. The first, which is the method most frequently used in New Zealand, is by the direct employment of scientists: this method he considers will remain important, though he rejects the idea that Government departments should be limited to applied research or services. The second method, that of using consultant firms, has not yet been used with complete satisfaction; however, the third, that of using non-profit organizations, while open to abuse, has proved valuable in financing university research. In New Zealand it is exemplified by earmarked grants to universities, and Dr. Williams suggests that the value of this work would be enhanced if the universities directed more attention to the nature of the applicants' interest in research in making appointments. The fourth method, that of the research association, he regards as one of the most worth-while for expansion, but he stresses the need for vigorous and enlightened direction. The fifth method, research in private industry, is weak in New Zealand, but Dr. Williams does not suggest that Government responsibility should extend beyond encouraging those firms who are willing to help themselves in this work. Finally, considering the proposed National Research Council, he points out that it is essential that it should have a strong representation of those with executive and advisory responsibilities.

A second paper in the same issue, by I. E. Dick, of the New Zealand Department of Scientific and Indus. trial Research, on science in industrial development, throws further light on the position of science in New Zealand and the outlook of scientists. Mr. Dick discusses more particularly the problems likely to confront scientists who may be called on to take an important part in determining policy in industrial development. He suggests that the value of a scientist at board-level depends very largely on his ability to view the whole complex of opera. tions in a thoroughly scientific manner. He should not regard his responsibility as limited to the technological problems with which his professional training has made him primarily familiar. Accordingly, he should be at particular pains to acquire technical understanding of these wider problems from the appropriate specialist periodicals.

Discussing the various ways in which science can be used to promote industrial development, Mr. Dick suggests that leaders in science and the appropriate scientific organizations in New Zealand are to-day, on the whole, displaying a lamentable lack of initiative, intellectual courage and foresight in regard to the choice of avenues of industrial development which look feasible and desirable, both technically and economically. In support of this contention, he cites the absence of a public statement, convincingly argued, on the part that science can play in industrial development or national life, and the excessive reliance of leading scientists in New Zealand on overseas scientists. He sees no merit in seeking solutions to problems in New Zealand from overseas scientists, and, while admitting that New Zealand has much to learn from overseas scientists, he suggests that such help can best be given in an advisory capacity to a committee of New Zealanders appointed to deal with a specific problem. Mr. Dick is convinced that New Zealand scientists are fully competent to handle the problems which confront them provided they are given competent leadership and public confidence.

\section{SEARCH FOR OIL IN AUSTRALIA}

$\mathrm{F}^{\mathrm{o}}$ OLLOWING the brief account of present petroleum exploration activities in Australia recently published in Nature $(200,123 ; 1963)$, two further official reports have been received giving details of drilling operations, both in Queensland*.

Publication No. 15 describes the Overflow No. 1 well drilled by the Queensland American Oil Co. on the South Moreton Anticline occurring in south-east Queensland. The target depth of this project was $6,500 \mathrm{ft}$., but it actually finished at $2,993 \mathrm{ft}$. The well was drilled in Bundamba Sandstone (Triassic) to $310 \mathrm{ft}$., thence in the Ipswich Coal Measures down to $1.605 \mathrm{ft}$., followed by a thick sequence of volcanic rocks of probable early Triassic or Upper Palrozoic age to the point where it was abandoned. It was found that minor oil and gas showings were associated with the coal seams, but poor petroleum prospects once the volcanic rocks were penetrated. coupled with extremaly hard drilling. determined the finish of operations some $3.500 \mathrm{ft}$. short of the horizon aimed at. This was an unusually short-lived project. the woll being spudded in on April 8, 1960, and abandoned as a dry hole

- Australia: Department of National Development. Bureau of Mineral Resources, Geology and Geophysics. Petroleum Search Subsidy Acts. Publication No. 15: Queensland American The Overflow No, 1, Queensland, of Queensland A merican Oil Company. Pp. $21+1$ plate. Publication No. 41: Phillips-Sunray Buckabie No. 1, Queensland of Phillips Petroleum Company and Sunray Mid-Comtinent Company. Pp. 43+1 plate (Canberra City, A.C.T.: Departonent of National Resour. on May 18, 1960. It is concluded that the South Moreton Anticline structure does not warrant further exploration largely because of the lack of porosity and permeability of the Ipswich Coal Measures, also the presence of a formidable development of volcanic andesites, basalts and trachytes, a series which certainly does not invite oil prospecting.

In Publication No. 41, an account is given of a much deeper venture, the Phillips-Sunray Buckabie No. I well. drilled by the Phillips Petroleum and Sunray MidContinent Oil Companies, carried to a total depth of $9.070 \mathrm{ft}$. It is reported that this hole penetrated a normal Cretaceous and Jurassic sequence of deposits known at this site (about 110 miles west of Charleville, southern Queensland) from previous water-borehole data, and accounting for some $5,000 \mathrm{ft}$. of strata. This woll was logged with electric, radiation and acoustic tools. "Regional seismic surveys indicated that the known section of the Great Artesian Basin overlies, with angular unconformity, stratified rock up to $15000 \mathrm{ft}$. thick. This deeper sequence had not been penetrated by the bit and its age and lithology over wide areas were completely unpredictable." Thus, although valuable geological knowledge of this part of the basin was gained as a result of this drilling, no appreciable shows of oil or gas were met with; when at $8.810 \mathrm{ft}$. the well entered a dense, steeply dipping metamorphosed mudstone, it was obvious that no further 
hope of success could be entertained and the site was abandoned as another dry hole after $260 \mathrm{ft}$. had been added to that depth.

Both these reports are admirably produced, and apart from including maps, plans, structural data and detailed well-logs, the geophysical, palæontological and petrological details obtained from the well-samples recovered are fully documented. Notwithstanding that both these Queensland projects merely add to the discouragingly long list of failures to find commercial oilpools in Australia, at least one success has to be recorded. With the start of a pipeline from the Moonie field to Brisbane, what is described as ". . . the beginning of the end of a long and arduous undertaking to produce Australia's first commercial oilfield" has undoubtedly given a fillip to oil exploration at least in this part of the Continent. According to The Australian Mineral Industry (16, No. 1, September 1963), the Moonie pipeline is to be equipped with one pumping station on the oilfield and it will initially be eapable of delivering up to 10000 barrels of crude oil per day. Should future developments and discoveries warrant it, the capacity of the line can be boosted to 57000 barrels per day; this would necessitate erection of three more pumping stations. There is definitely some hope in the Moonie area because one woll, Moonie No. 17, produced oil at the rate of 1,891 barrels per day through a $\frac{1}{2}$-in. choke during a production test on two zones, an upper and a lower; it is the second of 15 successful wells in this field to produce from these zones. A gas production rate of $213,000 \mathrm{ft}^{3}$ per day, also proved. lends further encouragement to continue the search.

H. B. MrLiter

\section{DOMESTIC FOOD CONSUMPTION AND EXPENDITURE IN BRITAIN, 196I}

$\mathrm{T}$ HE pattern of food supplies in 1961 was broadly similar to that in 1960 , but some trends in the level of supply of individual commodities continued. Thus supplies of milk, cream, cheese and eggs moving into consumption again increased while those of fish and flour continued to decline. Total supplies of meat rose to $128 \mathrm{lb}$. (edible weight) per head. The total level of supply of butter was almost as great as in 1958 and resulted in a curtailment of demand for margarine. Supplies of potatoes were slightly greater than in the previous year, but those of most fresh fruits and vegetables declined. These facts are given in the annual report of the National Food Survey Committee entitled Domestic Food Consumption and Expenditure, $1961 *$.

The Report is the twelfth of an annual series introduced in 1950 relating to consumption, expenditure and nutrition of private households in Great Britain. Evidence is also presented that, between 1956 and 1961, differences associated with social class and household composition have narrowed. Food expenditure increased at slightly higher * Ministry of Agriculture, Fisheries and Food. Domestic Food Consump-
tion and Expenditure, 1961 -Annual Report of the National Food Survey Committee. Pp. vili +124. (London: H.M.S.O., 1963.) 8s. 6d. net. rates in the lower income groups (including pensioner households) and in large families.

In one of the two special investigations, the report shows that the average numbers of earners and the average net income per household together with the food expenditure per person were slightly lower in families including an expectant mother than in those without. Also the differences in type of diet between larger and smaller households were accentuated when the housewife was pregnant. The other special investigation examines the impact on the demand for carcass meat of the expansion of the poultry industry between 1956 and 1961. This shows that since 1959 the consumption of carcass meat has not decreased in spite of increased consumption of poultry.

Apart from tables containing extensive data relating to consumption, nutrition and expenditure, the appendixes include an account of the methods used in conducting the survey and analysing the results. Although the National Food Survey is primarily intended to provide information for the Government, its findings should be of interest to all who are interested in nutritional and dietary matters and production of food for the home market. D. PEArson

\section{TOOTH REPLACEMENT IN THE MAMMAL-LIKE REPTILES}

$\mathbf{N}$ any attempt to derive the mammals from the reptiles, one of the problems encountered in the past has been the virtual impossibility of reconciling the apparently different methods of tooth replacement found in these two classes. Thus Dr. A. W. Crompton's recent analysis of the situation in some of the most mammalian of the mammallike reptiles, the cynodonts, is of considerable interest, for he demonstrates that within this small group both types of dentition are represented *.

From a more complete series of developmental stages than has hitherto been known, Dr. Crompton confirms in Thrinaxodon Parrington's contention that the teeth are replaced alternately, and he shows further that the wave of replacement passes from back to front along both the odd and even teeth, exactly as in typical reptiles. This is despite the mammalian appearance of the teeth themselves. In the gomphodont cynodonts, on the other hand, Crompton observes that in contrast to the situation in Thrinaxodon, the replacement is from front to back, while there is no sign of an alternate succession. This latter dentition therefore parallels that seen in the mammals.

* Annals of the South African Museum, 46, Part 20: Tooth Replacement in the Cynodont Thrinaxodon liorhinus Seeley. By A. W. Crompton. Pp. 479521. (Cape Town: South African Museum, 1963.) 75 cents.
Crompton's observations thus help to confirm the theory recently postulated by Edmund on tooth replacement patterns (Contrib. Roy. Ontario Mus., Life Sci. Div., 52, 1; 1960). He suggests that impulses travel along the dental lamina initiating the development of successive tooth germs, and where consecutive impulses are spaced at a distance of twice that between tooth germs, then a fully alternate dentition results. If, however, there is slightly more than this distanee between impulses, there is a time lag before the more anterior teeth appear, so that the wave of replacement of both odd and even teeth will appear to be from back to front of the jaw. If the interval is less than twice this distance, then the wave will appear to travel in the reverse direction.

Edmund further believes that each animal possesses more than one generation of teeth, or Zahnreihe, and, again using Edmund's theory, Crompton shows that in Thrinaxodon there is an endless succession of Zahnreihen, while in the gomphodont cynodonts there are only two, part of the second being suppressed. It is this reduction of Zahnreihen which accounts for the lack of an alternate succession in the gomphodont cynodonts, as it does in the mammals where part of the second Zahnreihe is also sup. 